\title{
Characterization of Olive (Olea Europaea L.) Genetic Resources via PCR-Based Molecular Marker Systems
}

\author{
S. Galatali, N. Abdul Ghafoor, and E. Kaya
}

\section{ABSTRACT}

\begin{abstract}
Olea europaea L., which is one of the ancient culture species cultivated in the Mediterranean area, has approximately 1200 cultivars. Its wild thype forms from $O$. europaea subsp. europaea var. sylvestris and its culture type forms from O. europaea subsp. europaea var. europaea. Olive cultivation is multiplied by grafting or cutting whereas wild type olive seedlings derived from seeds of $O$. europaea $L$. var. sylvestris. Because they have very big level heterozygosities, the genetic diversity of olive cultivars is quite high that they are predominantly allogamus. This genetic variability causes many confusions for identification of olive cultivars and since both oil quality and olive productivity are traits inherited to a variety, it is urgently needed to solve characterization and evaluation of olive genetic resources. The molecular marker systems are independent from environmental factors and effective technology to both detect homonymous and synonymous of cultivars and identify olive varieties. The current review is aimed to present molecular marker systems for identification and characterization of olive cultivars and emphasize their application for conservation of olive germplasm.
\end{abstract}

Keywords: Molecular Characterization, Olive (Olea europaea L.), PCR-Based Marker System.

\section{INTRODUCTION}

The Mediterranean Region today meets $98 \%$ of the world olive oil production with approximately 2000 varieties [1]. Its propagation to different regions from this original region where it was cultured makes olive one of the most important garden plants and makes the work required for preserving its germplasm very important [2].

The genetic basis of today's olive cultivation in Mediterranean countries is primarily related to experiencebased techniques and agricultural production. Although olives grown today have been structurally preserved, their productivity and quality are owed to the ongoing clonal selection since many years [3].

Adaptation, which is seen as the most important distinguishing feature of a species, can be defined as the fitness that an individual develops in order to survive in a unique environment in which he or she grows. Although adaptation was not done consciously in early selection studies, it played a crucial role in the formation of different varieties with high specificity a particular environment but not very well adapted to other environments [1], [4].

In the past, many studies have been realized using morphological, biochemical and molecular procedures in order to determine the many varieties that exist in local plant materials among olive producing Mediterranean countries. However, since the nature and discrimination power of the criteria applied in these studies are very different from each other, very little information could be obtained about the
Published Online: February 10, 2021

ISSN: $2684-5199$

DOI: $10.24018 /$ ejbio.2021.2.1.146

\section{S. Galatali}

Mugla Sitki Kocman University, Mugla, Tukey.

(e-mail: selin_5308@hotmail.com)

N. Abdul Ghafoor

Mugla Sitki Kocman University, Mugla, Tukey.

(e-mail: merzanaeem007@gmail.com)

E. Kaya*

Mugla Sitki Kocman University, Mugla, Tukey.

(e-mail: ergunkaya@mu.edu.tr)

*Corresponding Author diverse the olive tree structure, especially the number of genotypes spread over different areas [3], [5].

Since the structure of olive genetic resources is not well known, even the most known varieties have different names in the areas where they are cultivated. Another more common problem is that when varieties that are actually different from each other have a common unique character (usually related to the shape and size of the fruit or many other visible features), they are referred to by the same name. For this reason, information is needed about the local materials of olive-growing countries in order to classify existing varieties and to examine the genetic resources of olives by revealing unknown genotypes. This is particularly accelerated by the development of possible new varieties in ongoing breeding programs in the midterm and the risk of genetic erosion resulting from the fact that most of today's olive groves are in marginal areas [6], [7].

Even in the times of the Romans, great importance was attached to the classification and identification of cultivated olive plants and the agronomists of that time were able to distinguish the varieties of this plant type according to their interesting agricultural characteristics. There are descriptions of these varieties made by Cato, Varno, Virgil and other researchers in the literature, however, it is hard to determine a similarity between these cultivars and those that are cultivated today. Most of these varieties have either disappeared due to different environmental conditions (e.g., frost, drought, parasites) or have changed due to crosses with other varieties, mutations and/or selections based on producers' requirements [8]. 
Over time, studies carried out by many researchers determined a big number of olive cultivars by taking into account their more variable characteristics. Since these studies mostly concern individual trees, regardless of whether they belong to a known variety or not, the accumulated data were too much and these results have confused even the farmers and other cultivators [9]. One of the most important challenges is identifying the differences between all these cultivars, often defined by the local dialect, and another one is to establish links between results from different areas. The first results obtained from a researched olive region compared to other regions revealed a large number of homonyms (for example, different olive varieties have the same name in dissimilar regions) and synonym (for example, a cultivar identified in one area has a different name in another area). The same problem continues today for scientists and cultivators [8], it is estimated that the olive germplasm actually contains more than 1200 varieties. The exact number of olive varieties in the world counts as approximately 4000 different varieties due to the numerous homonyms and synonyms mentioned above [3].

Traditionally, morphological and physiological characteristics are used to determine olive varieties. It has now been found that isozymes are useful for determining varieties and kinship between varieties. Since the 1970's, protein analysis (total proteins and/or storage proteins) has been one of the most important methods used to distinguish species and varieties. Among these, storage proteins are the most suitable for use as molecular marker systems. Compared to other biochemical markers, protein analysis has the benefit that the extraction and separation procedure is simple, although it ensures less data about genetic diversity. Pontikis et al. [10] identified 27 olive varieties, most of which were of Greek origin, using the enzyme system in their pollen. Later, Trujillo et al. [11] was able to distinguish 134 of 155 varieties using 5 enzyme systems found in pollen. Further on, Ouanzani et al. [12] was able to identify 33 of 44 varieties using nine enzyme systems in the leaf tissue. In addition to these studies, seed storage proteins and total leaf proteins were investigated in the olive plant for the same purpose [13], however, evaluation of the results obtained with isozymes is difficult due to the possible different gene expression levels and tissue specificity in plants [14]. Although isozyme analyzes have proven to be useful in olives, because of the high level of polymorphism available in the cultivars, direct analysis of DNA can significantly rise the many molecular markers developed.

Nowadays, many PCR-based marker systems are used, which are highly effective and widely tested in determining the high polymorphism seen in olive varieties and identifying varieties. In this review, it is aimed to define the importance of PCR-based marker systems in characterization to define the widely used marker systems for olive plants and to emphasize the recent studies.

\section{ORIGIN OF OLEA EUROPAEA L.}

Olive, covering a part of the Southeastern Anatolia Region of Turkey and Syria has originated from the upper Mesopotamia and southwestern Asia. Culturing olive started in the Mediterranean around $3000 \mathrm{BC}$ and made it one of the first varieties cultured in this region [2].

Recent mitochondrial analyzes showed that wild Mediterranean olives originated from 2 different places, one in the Near East and the other in Maghreb (Northwest Africa) [15] It is thought that the cultivation of olives probably started 5500 years ago following the human migration of the wild Mediterranean olive known as "Oleaster" back then, which then started to spread throughout Southern Europe and North Africa [16]. The original improving of the olive germplasm is based on the determination and selection of the best trees, which in addition to the vegetative propagation marks the beginning of the clonal genetic basis of varieties.

\section{MOLECUlAR BASED MARKER SYSTEMS IN THE CHARACTERIZATION OF OLIVE VARIETIES}

Recently, in parallel with advances in biomolecular and biochemical marker techniques, the usage of molecular fingerprint methods has been started [10], [12], [17]. The use of molecular markers, especially the environmental factors independent high resolution differentiation system, produces' relatively reliable results for diversity protection and/or certification of geographic origin [14], [18] and it enabled the identification of misnamed olive varieties found in the germplasm collections.

The first molecular marker method applied to olive is Restriction Fragment Length Polymorphism (RFLP) [19]. This technique has also been used in the analysis of 95 plants obtained by crossing two varieties ('Leccino' and 'Dolce Agogia'). RFLP markers have confirmed that this fruit was cultured in the Mediterranean Region [16]. Another molecular marker technique used in olive plants for the same purpose is Random Amplification of Polymorphic DNA (RAPD). RAPD analysis, developed by Williams et al. [20] and Welsh and McClelland [21], is a useful tool that can be used in genetic fingerprinting and mapping studies.

Numerous molecular markers have been applied to different olive varieties, often giving interesting results. Although there are many varieties in our country (Turkey), which is considered among the important olive producers, the number of studies based on the use of molecular markers in distinguishing these varieties is quite limited. For this reason, it's of great importance to determine the olive varieties in our country using genetic marker systems.

\section{A. Random Amplification of Polymorphic DNA (RAPD)}

RAPD procedure is one of the PCR-based DNA marker systems, it is based on the multiplication of DNA fragments using only a primer with random nucleotide sequence [20]. RAPD molecular markers are generally dominant and thus cannot distinguish individuals with heterozygous genotype from homozygous individuals. However, since DNA does not need to be cut and hybridized with restriction enzymes, RAPD analyzes are performed in a relatively shorter time and with less effort than RFLP markers.

The RAPD technique has been used by many researchers for olive plant [22]-[30]. The technique has also been tested by Gemas et al. [31] and Roselli et al [32] to evaluate the differences between and within varieties. Both RAPD and RFLP contributed properly to the systematic classification of the Olea genus [33]. 


\section{B. Amplified Fragment Length Polymorphism (AFLP)}

Another molecular marker system used in determining the differences between olive varieties is AFLP which gives very productive results in the detection of polymorphisms in the whole genome [34]. AFLP analysis is a technique that can rapidly provide information on the genetic basis of selected series or populations. A much higher percentages of polymorphic bands are produced per analysis with AFLP techniques relative to markers such as RAPD and RFLP. AFLP DNA analysis is a multi-step technique that consists of digesting DNA, attaching fragments to adapters, selective PCR amplification and separation of fragments [35]. The differences that can be seen between the results obtained in different laboratories in the analysis of plant DNA with AFLP are caused mainly due to low DNA quality or low DNA concentration, incomplete digestion process and/or not choosing the correct PCR primers correctly [36], [37].

AFLP has become a valid tool in population genetics and molecular evolution studies. Analyzes based on automatic capillary are performed differently in slab gel. In slab gel applications, denaturing gel electrophoresis is used to separate radiolabeled primers and fragments in the selective amplification stage. Nowadays, analysis systems with separation capacities that allow single base differences in fragments with certain sizes to be distinguished have come into play and fragments can be separated by capillary electrophoresis. Although AFLP markers are not suitable for identifying phylogenetic relationships, they are very effective for extracting genetic fingerprints among closely related taxa and individuals. Considering the high number of individuals to be genotyped in mapping projects, a protocol suitable for DNA for all plant species should be established in order to obtain results that produce distinctive, accurate and reproducible fragments [38]-[40].

By using AFLP markers, the evaluation of genetic kinship between different forms of olives and cultivated olive varieties has been established, therefore contributing to the understanding of the genetic relationships that distinguish the forms belonging to different geographic regions [41], [42].

Polymorphism obtained with isozymes is not sufficient for applications such as the identification of cultures, detailed germplasm analysis and/or selection using markers. Although RAPD markers give a more distinctive profile, their very difficult reproducibility limits their use in identifying cultures, locating loci and determining their location. Combining the enzymatic digestion of DNA with the selective amplification of fragments, AFLP is widely used in genetic mapping applications, germplasm analysis and culture identification, as a highly reproducible genetic marker [43].

When compared with other studies, it has been observed that AFLPs have 3-8 times more multiplex rate than RAPDs in olive analysis. This high multiplex ratio, combined with the trustworthiness of the data, shows that the AFLP technique can be used efficiently in the determination of olive varieties [43]. AFLP, a fast and reproducible method of DNA fingerprinting that produces a large number of polymorphisms based on the determinative amplification of restriction fragments by PCR from total genomic DNA digested with certain restriction enzymes, has also been successfully used to reveal genetic relationships within a wide variety of species [38]-[41], [44], [45].

\section{Microsatellite Polymorphism (SSR, Simple Sequence Repeats)}

Simple sequence repeats markers known as SSR have shown very successful results in differentiating genotypes due to their highly polymorphic and codominant nature and their widespread distribution in the plant genome [46], [47]. They are preferred due to their convenience in distinguishing clonal populations derived from vegetative propagation, especially as in olive varieties [48]. However, since the aforementioned properties of microsatellites require sequence knowledge, great efforts are required initially to design these markers [49].

The first SSR marker tested in the olive family (Oleaceae) was identified in ash tree (Fraxinus excelsior L.) by Lefort et al. [50]. The first 5 SSR markers for olive varieties were determined one year after this study (IAS series), Rallo et al. [51]. Thanks to the polymorphism provided by SSR markers tested in 46 varieties in total, 26 alleles and 42 varieties were separated from each other. At the same time, Sefc et al. [52] published another important 15 SSR olive loci (DCA series). These markers (4-15 alleles per locus) were tested in 38 Iberian and 9 Italian cultivars.

SSR markers were successfully used by many olive research groups because of the high polymorphism they reveal. In addition, 3 studies were published in 2002 reporting the development of independent SSR loci. These are, Ciprani et al. [53], 30 microsatellite loci (UDO series) tested in 12 varieties, Carriero et al. [54], 20 different loci (GAPU series) analyzed in 16 different types, showing an average of 5.7 alleles, and finally De la Roza et al. [55], 7 single-locus polymorphic microsatellites (EMO series) that can distinguish 23 varieties respectively.

The first detailed report on distinguishing olive varieties using SSR was published by Bandelj et al. [56]. These researchers used 14 microsatellite markers (DCA series) to distinguish 19 olive varieties. Later, 35 Spanish and Italian olive varieties with commercial importance were analyzed using 9 SSR primers (UDO series) [57]. The first study to characterize olive germplasm at the regional level was carried out using SSR markers in many local varieties in Sicily [58]

\section{Inter Simple Sequence Repeat (ISSR) Polymorphism}

For some characterization studies that require high precision, ISSR marker systems have been developed in order to eliminate the low reproducibility disadvantages of SSR marker systems, the high cost of RADP and the need for preliminary sequence information of AFLP [59], [60]. This marker system aims to reproduce the region (200-2000 base pairs) between two close microsatellites. ISSR markers represent the specificity of microsatellite markers without requiring a preliminary sequence data for primer synthesis. ISSR molecular markers, single or in combination with other molecular markers, are widely used in determining the genetic diversity of olive culture races and in analyzing their clonal changes [60]-[65]. In the first studies with ISSR marker systems, it was found to be effective in determining phylogenetic kinship degrees of $O$. europaea species $[61,66]$ and in the determination of olive fruit and leaves [67]. 


\section{E. Sequence-Characterized Amplified Region (SCAR) Polymorphism}

Many modified molecular markers have been developed since the advent of PCR-based molecular markers. In the certification of fruit gardens and growth areas, naming of the source as protected (PDO, Protected Denomination of Origin) is important, and for this, a fast and effective technique for the identification of culture breeds needs to be developed. The development of culture-specific molecular marker systems may be beneficial in the olive industry, especially for selecting culture breeds that are important in improving oil quality [68], [69].

SCAR polymorphism is widely used in food products, especially in the plant food industry, such as wheat [70], grape [71], tomato [72] and pear [69], [73]. SCAR marker systems in olives are especially used for the diagnosis and mapping of olive germplasm [74]-[76] and for the analysis of industrial varieties [68].

\section{F. Single Nucleotide Polymorphism (SNP)}

Single nucleotide polymorphism is a molecular marker system based on identifying the difference at a single nucleotide level on the genome. These differences are abundant in the genomes of many species, including plants [77]. SNP-based molecular markers have been widely used in many plants, including olives [78].

\section{G. Inter Retrotransposon Amplified Polymorphism (IRAP)}

Density of retrotransposons in the plant genome [79], [80], their distribution [81], [82] and presence [80], [83], [84] allows for the development of a perfect marker system. Transposons, like retroviruses, replicate successfully with the insertion of a new cDNA by reverse transcription within the genome [85]. The structure of retrotransposons and their replication strategy provide a number of advantages as markers. The first of these advantages is that they include long defined and protected nucleotide sequences that can be used for cloning retrotransposons, proximal sequences and specific markers. The second one is that the active replicative members of a family of retrotransposons can produce new insertions in the genome that will lead to polymorphism. These new insertions can be identified and used in a lineage helping to establish phylogeny [86]. This marker system was first used in 2014 by Koksal et al. It was used in the molecular characterization study of 20 individuals belonging to four different local olive varieties and in the molecular characterization of 8 Turkish and 2 Italian olive varieties by Kaya and Y1lmaz Gokdogan in 2016 [87], [88].

\section{IMPORTANT STUDIES ON MOLECULAR CHARACTERIZATION OF OLIVE GERMPLASM}

There are numerous studies by many researchers to determine the high polymorphism seen in olive varieties and to define the varieties. Some important studies carried out in different countries using different marker systems on the olive plant are given in Table 1.
TABLE I: MAJOR STUDIES BASED ON MOLECULAR MARKER SYSTEMS FOR CHARACTERIZATION OF OLIVE GERMPLASM

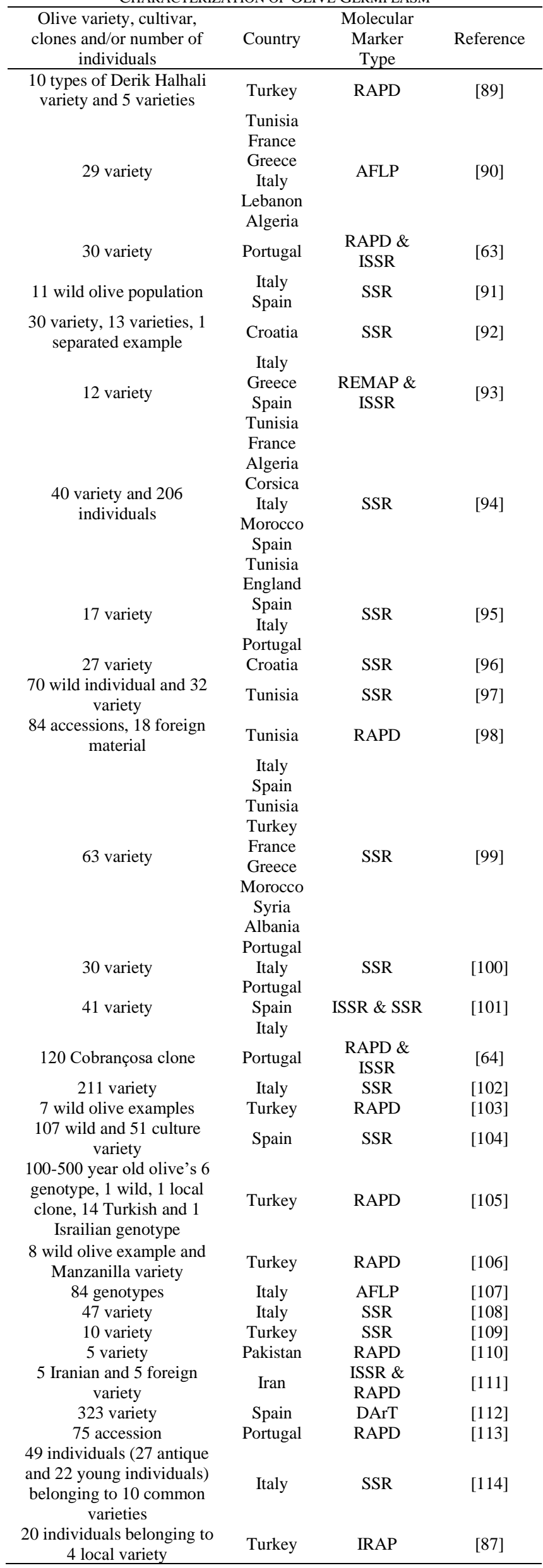




\section{RESUlts}

Nowadays, the olive industry requires the certification of olive culture breeds with superior agricultural characters and adapted to modernized orchards [17]. While quite a few cultivars are grown commercially in a region or country, most cultivars are distributed in a local area. The homonymous and synonym states of the cultivars are associated with a high rate of genetic differentiation in the germplasm of olive trees, which is very difficult to characterize. For more than two decades, PCR-based marker systems have provided great opportunities for the development of new molecular techniques for the diagnosis of culture varieties and for further certification studies. Unlike other methods such as characterization and comparison of phenotypic and agronomic data, molecular marker systems are based on genetic-based study of olive germplasm. Different multicultural marker systems are used to determine the degree of kinship between cultural varieties.

\section{CONCLUSION}

Determining which molecular marker system is more appropriate in characterizing olive genetic resources depends on a number of factors such as the differentiation levels of the species and the accessibility of resources [115]. Technological advances contribute to the development of the advantageous molecular marker systems, such as the ones that are technically simpler, more efficient, low cost and more rapid than conventional procedures. Regardless of all, molecular approaches can provide more effective results in studies such as the evaluation of olive genetic diversity, not alone, but in combination with other approaches. Many molecular markers used in various germplasm studies can be of great importance in olive tree production programs, with studies such as determination of olive fruit and oil quality, identification of biotic and abiotic stress tolerance.

\section{ACKNOWLEDGMENT}

The current work is dedicated to Prof. Dr. Fusun Gumusel, previous head of the Molecular Biology and Genetics Department of the Gebze Technical University, who passed away in 2012; the authors will be thankful for her great scientific support and valuable friendship.

\section{REFERENCES}

[1] G. Bartolini and R. Petruccelli, Classification, Origin, Diffusion, and History of the Olive, Rome, Food and Agriculture Organization of the United Nations, 2002, pp. 43.

[2] D. Zohary and P. Spiegel-Roy. "Beginning of Fruit Growing in the Old World," Science, vol.187, pp. 319-327, 1975.

[3] G. Bartolini, G. Prevost, C. Messeri and G. Carignani. Olive Germplasm: Cultivars and World-Wide Collections. FAO, Rome, 1998.

[4] D. Barranco, A. Cimato, P. Fiorino, L. Rallo, A. Touzani, C. Castaneda and I. Trujillo. "World Catalogue of Olive Varieties," International Olive Oil Council, Madrid, Espanha. 2000.

[5] M.G. Claros, R. Crespillo, M.L. Aguilar and F.M. Cánovas. "DNA Fingerprinting and Classification of Geographically Related Genotypes of Olive-Tree (Olea europaea L.)," Euphytica, vol. 116, pp. 131-142, 2000.

[6] D. Barranco and L. Rallo. "Las Variedades de Olivo Cultivadas en Andalucia Consejeria de la Junta de Andalucia,” Madrid. MAPA, 1984.
[7] G. Prevost, G. Bartolini and C. Messeri. "Cultivar Italiane di Olivo e Loro Sinonimi," Lucca. Menegazzo, 1993.

[8] T. Ganino, G. Bartolini and A. Fabbri. "The Classification of Olive Germplasma Review," The Journal of Horticultural Science and Biotechnology, vol. 81, no. 3. pp. 319-334, 2006.

[9] G. Caruso. "Monografia dell' Olivo," In Enciclopedia agnia Italiano. 3(5), UTET, Turin, Italy. 1983.

[10] C.A. Pontikis, M. Loukas and G. Kousounis. "The Use of Biochemical Markers to Distinguish Olive Cultivars," The Journal of Horticultural Science, vol. 55, no. 4. pp. 333-343, 1980.

[11] I. Trujillo, L. Rallo, E.A. Carbonell and M.J. Asins. "Isoenzymatic Variability of Olive Cultivars According to Their Origin," Acta Horticulturae, vol. 286, pp. 137-140, 1990.

[12] N. Ouazzani, R. Lumaret, P. Villemur and F. Di Giusto. "Leaf Allozyme Variation in Cultivated and Wild Olive Trees (Olea europaea L.)," Journal of Heredity, vol. 84, pp. 34-42, 1993.

[13] M. Durante, E. Attina, S. Nardi, G. Cacco. "Changes Induced by Humic Substances and Nitrate in the Genomic Structure of Wheat Roots," In: Senesi, N., Miano, T.M., (Eds.), Sixth International Meeting of IHSS, Monopoli (Bari), pp. 149. 1992.

[14] W. Povel, M. Morgante, C. Andre, M. Hanafey, J. Vogel, S. Tingay and A. Rafalski. "The Comparisons of RFLP, RAPD, AFLP, and SSR (Microsatellite) Markers for Germplasm Analysis," Molecular Breeding, vol. 2, pp. 225-238, 1996.

[15] G. Besnard and A. Berville. "On Chloroplast DNA Variations in the Olea europaea L. Complex: Comparison of RFLP and PCR Polymorphisms," Theoretical and Applied Genetics, vol. 104, pp. 1157-1163, 2002.

[16] G. Besnard, C. Breton, P. Baradat, B. Khadari and A. Bervillé. "Cultivar Identification in Olive Based on RAPD Marker," Journal of the American Society for Horticultural Science, vol. 126, no. 6. pp. 668-675, 2001.

[17] P. Hatzopoulos, G. Banilas, K. Giannoulia, F. Gazis, N. Nikoloudakis, D. Milioni and K. Haralampidis. "Breeding, Molecular Markers and Molecular Biology of the Olive Tree," European Journal of Lipid Science and Technology, vol. 104, pp. 574-586, 2002.

[18] R. Testolin, M.T. Marrazzo, G. Cipriani, R. Quarta, I. Verde, M.T. Dettori, M. Pancaldi and S. Sansavini. "Microsatellite DNA in Peach (Prunus persica L. Batsch) and its Use in Fingerprinting and Testing the Genetic Origin of Cultivars," Genome, vol. 43, pp. 512-520, 2000.

[19] M. Gallitelli, L. Semeraro and N.M. Antonelli. RFLP Analysis in the Olive (Olea europaea L.), EMBO Course, 1991, Cologne.

[20] J.G.K. Williams, A.R. Kubelik, K.J. Livak, J.A. Rafalski, S.V. Tingey. "DNA Polymorphisms Amplified by Arbitrary Primers are Useful as Genetic Markers," Nucleic Acids Research, vol. 18, pp. 6531-6535, 1990.

[21] J. Welsh and M. McClelland. "Fingerprinting Genomes Using PCR with Arbitrary Primers," Nucleic Acids Research, vol. 18, pp. 7213$7218,1990$.

[22] P. Bogani, D. Cavalieri, R. Petruccelli, L. Polsinelli and G. Roselli. "Identification of Olive Tree Cultivars by Using Random Amplified Polymorphic DNA,” Acta Horticulturae, vol. 356, pp. 98-101, 1994.

[23] A. Fabbri, J.I. Hormaza and V.S. Polito. "Random Amplified Polymorphic DNA Analysis of Olive (Olea europaea L.) Cultivars," Journal of the American Society for Horticultural Science, vol. 120, pp. 538-542, 1995.

[24] E. Perri, R. Sirianni, G. Godino and S. Tartarini. "Characterization of Italian Olive (Olea europaea L.) Cultivars by Satistical and Molecular Methods," Acta Horticulturae, vol. 474, no. 2. pp. 489-493, 1999.

[25] M. Gonzalo-Claros, Crespillo, R. Aguilar, M.L. Cánovas and F.M. "DNA Fİngerprinting and Classification of Geographically Related Genotypes of Olive-Tree (Olea europaea L.)," Euphytica, vol. 116, pp. 131-142, 2000.

[26] A. Belaj, I. Trujillo, R. De la Rosa, L. Rallo and M.J. Gime'nez. "Polymorphism and Discrimination Capacity of Randomly Amplified Polymorphic Markers in an Olive Germplasm Bank," Journal of the American Society for Horticultural Science, vol. 126, pp. 64-71, 2001.

[27] R.J. Mailer and C.E. May. "Variability and Interrelationships of Olive Trees and Cultivars Using RAPD Analysis," Advances in Horticultural Sciences, vol. 16, no. 3-4. pp. 192-197, 2002.

[28] A. Fabbri and T. Ganino, "Il Germoplasma Olivicolo in Emilia," Atti Convegno Germoplasma Olivicolo e Tipicita` dell'olio Perugia, 2003, pp 48-52.

[29] N. Mir Ali and I. Nabulsi. "Genetic Diversity of Almonds (Prunus dulcis) Using RAPD Technique," Scientia Horticulturae, vol. 98, pp. 461-471, 2003.

[30] T. Ganino and A. Fabbri, "Genetic Characterization of Olea europaea L. Germplasm in Northern Italy," 5th International Symposium on Olive Growing, Izmir (Turkey), 27 September-2 October, 2004. 
[31] V.J. Gemas, M.J. Rijo-Johansen, R. Tenreiro and P. Fevereiro. "InterVarietal and Intra-Varietal Analysis of 3 Olea europaea L. Cultivars Using the RAPD Technique," The Journal of Horticultural Science and Biotechnology, vol. 75, pp. 312-319, 2000.

[32] G. Roselli, L. Petruccelli, L. Polsinelli and D. Cavalieri. "Variability in Five Tuscan Olive Cultivars (Olea europaea L.)," Journal of Genetics and Breeding, vol. 56, pp. 51-60, 2002.

[33] G. Besnard, B. Khadari, P. Baradat and A. Berville'. "Olea europaea (Oleaceae) Phylogeography Based on Chloroplast DNA Polymorphism," Theoretical and Applied Genetics, vol. 104, pp. 1353 1361, 2002.

[34] D.G. Ranamukhaarachchi, M.E. Kane, C.L. Guy and Q.B. Li "Modified AFLP Technique for Rapid Genetic Characterization in Plants," BioTechniques, vol. 29, pp. 858-866, 2000.

[35] P. Vos, R. Hogers, M. Bleeker, M. Reijans, T. Vande, Lee, M.Hornes, A. Frijters, J. Pot, J. Peleman, M. Kuiper and M. Zabeau. "AFLP: a New Technique for DNA Fingerprinting," Nucleic Acids Research, vol. 23, pp. 4407-4414, 1995.

[36] R.R. Prabhu and P.M. Gresshoff. "Inheritance of Polymorphic Markers Generated by DNA Amplification Fingerprinting and Their Use as Genetic Markers in Soybean,” Plant Molecular Biology, vol. 26, pp. 105-116, 1994

[37] J. Lu, M.R. Knox, M.J. Ambrose, J.K.M. Brown and T.H.N. Ellis. "Comparative Analysis of Genetic Diversity in Pea Assessed by RFLPand PCR-Based Methods," Theoretical and Applied Genetics, vol. 93, pp. 1103-1111, 1996.

[38] M. Hill, H. Witsenboer, M. Zabeau, P. Vos, R. Kesseli and R. Michelmore. "PCR-Based Fingerprinting Using AFLPs as a Tool for Studying Genetic Relationships in Lactuca spp.," Theoretical and Applied Genetics, vol. 93, pp. 1202-1210, 1996.

[39] S.K. Sharma, M.R. Knox and T.H.N. Ellis. "AFLP Analysis of the Diversity and Phylogeny of Lens and its Comparison with RAPD Analysis," Theoretical and Applied Genetics, vol. 93, pp. 751-758, 1996.

[40] D. Milbourne, R. Meyer, J.E. Bradshaw, E. Baird, N. Bonar, J. Provan, W. Powell and R. Waugh. "Comparison of PCR-Based Marker Systems for the Analysis of Genetic Relationships in Cultivated Potato," Molecular Breeding, vol. 3, pp. 127-136, 1997.

[41] A. Angiolillo, M. Mencuccini and L. Baldoni. "Olive Genetic Diversity Assessed Using Amplified Fragment Length Polymorphisms," Theoretical and Applied Genetics, vol. 98, pp. 411-421, 1999.

[42] O. Ambrosino and R. Rao, "Marcatori AFLP per la Valutazione Della Variabilità Genetica Intra-Intervarietale in Cultivar di Olivo," Atti VI Convegno Nazionale Biodiversità, 2001, vol 2, pp. 397-405.

[43] P. Resta, C. Lotti, G. Fanizza, A. Godini, R. Mariani and M. Palasciano. "Use of AFLP to Characterize Apulian Olive Varieties," Acta Horticulturae, vol. 586, pp. 73-77, 2002.

[44] P.J. Maughan, M.A. Saghai, G.R. Maroof and G.M. Buss, Huestis. "Amplified Fragment Length Polymorphism (AFLP) in Soybean: Species Diversity, Inheritance and Near-Isogenic Line Analysis," Theoretical and Applied Genetics, vol. 93, pp. 392-401. 1996.

[45] V. Hongtrakul, G.M. Huestis, S. Knapp. "Amplified Fragment Length Polymorphism as a Tool for DNA Fingerprinting Sun-Flower Germplasm: Genetic Diversity among Oilseed Inbred Lines," Theoretical and Applied Genetics, vol. 95, pp. 400-407, 1997.

[46] M.J. Aranzana, A. Pineda, P. Cosson, E. Dirlewanger, J. Ascasibar, G. Cipriani, C.D. Ryder, R. Testolin, A. Abbott, G.J. King, A.F. Iezzoni and P. Arús, A "Set of Simple-Sequence Repeat (SSR) Markers Covering the Prunus Genome," Theoretical and Applied Genetics, vol. 106 , pp. 819-825, 2003.

[47] A.M. Cheng, M.W. Byrom, J. Shelton and L.P. Ford. "Antisense Inhibition of Human miRNAs and Indications for an Involvement of miRNA in Cell Growth and Apoptosis," Nucleic Acids Research, vol. 33, pp. 1290-1297, 2005.

[48] T. Thiel, W. Michalek, R.K. Varshney and A. Graner. "Exploiting EST Databases for the Development and Characterization of Gene-Derived SSR-Markers in Barley (Hordeum vulgare L.)," Theoretical and Applied Genetics, vol. 106, pp. 411-422, 2003.

[49] M. Morgante, A. Pfeiffer, I. Jurman, G. Paglia and A.M. Olivieri, "Isolation of Microsatellite Markers in Plants," in Molecular Tools for Screening Biodiversity, A. Karp, P.G. Isaac, D.S. Ingram, Ed. Plants and Animals, 1998, pp. 75-134

[50] F. Lefort, S. Brachet, N. Frascaria-Lacoste, K.J. Edwards, G.C. Douglas. "Identification and Characterization of Microsatellite Loci in Ash (Fraxinus excelsior L.) and Their Conservation in the Olive Family (Oleaceae)," Molecular Ecology, vol. 8, pp. 1075-1092, 1999.

[51] P. Rallo, G. Dorado and A. Martin. Development of Simple Sequence Repeats (SSRs) in Olive Tree (Olea europaea L.)," Theoretical and Applied Genetics, vol. 101, pp. 984-989, 2000.
[52] K.M. Sefc, M.S. Lopes, D. Mendonça, M. Rodrigues Dos Santos, M Laimer Da Camara Machado and A. Da Camara Machado. "Identification of Microsatellite Loci in Olive (Olea europaea) and Their Characterization in Italian and Iberian Olive Trees," Molecular Ecology, vol. 9, pp. 1171-1173, 2000.

[53] G. Cipriani, M.T. Marrazzo, G. Di Gaspero and R. Testolin. "DNA Microsatellite in Fruit Crops: Isolation, Length Polymorphism, Inheritance, Somatic Stability, and Cross-Species Conservation," Acta Horticulturae, vol. 546, pp. 145-150, 2000.

[54] F. Carriero, G. Fontanazza, F. Cellini and G. Giorio. "Identification of Simple Sequence Repeats (SSRs) in Olive (Olea europaea L.)," Theoretical and Applied Genetics, vol. 104, pp. 301-307, 2002

[55] R. De la Rosa, C. James and K.R. Tobutt. "Isolation and Characterization of Polymorphic Microsatellite in Olive (Olea europaea L.) and Their Transferability to Other Genera in the Oleaceae," Primer Notes. Molecular Ecology Notes, vol. 2, pp. 265 267, 2002.

[56] D. Bandelj, J. Jakse and B. Javornik. "DNA fingerprinting of Olive Varieties by Microsatellite Markers," Food Technology and Biotechnology, vol. 40, no. 3. pp. 185-190, 2002.

[57] A. Belaj, G. Cipriani, R. Testolin, L. Rallo and I. Trujillo. "Characterization and Identification of the Main Spanish and Italian Olive Cultivars by Simple-Sequence-Repeat Markers," HortScience, vol. 39, no. 7. pp. 1557-1561, 2004.

[58] M. La Mantia, O. Lain, T. Caruso, R. Testolin. "SSR-Based DNA Fingerprints Reveal the Genetic Diversity of Sicilian Olive (Olea europaea L.) Germplasm," The Journal of Horticultural Science and Biotechnology, vol. 80, pp. 628-632, 2005.

[59] E. Zietkiewicz, A. Rafalski and D. Labuda. "Genome Fingerprinting and Simple Sequence Repeat (SSR)-Anchored Polymerase Chain Reaction Amplification," Genomics, vol. 20, pp.176-183, 1994.

[60] P.J. Terzopoulos, B. Kolano, P.J. Bebeli, P.J. Kaltsikes and I. Metzidakis. "Identification of Olea europaea L. Cultivars Using InterSimple Sequence Repeat Markers," Scientia Horticulturae, vol. 105, pp. 45-51, 2005

[61] V.J.V. Gemas, M.C. Almadanim, R. Tenreiro, A. Martins and P. Fevereiro. "Genetic Diversity in the Olive Tree (Olea europaea L. subsp. europaea) Cultivated in Portugal Revealed by RAPD and ISSR Markers," Genetic Resource and Crop Evolution, vol. 5, pp. 501-511, 2004.

[62] S. Gomes, P. Martins-Lopes, J. Lima-Brito, J. Meirinhos, J. Lopes, A Martins and H. Guedes- Pinto. "Evidence of Clonal Variation in Olive 'Verdeal-Transmontana' Cultivar Using RAPD, ISSR and SSR Markers," Journal of Horticultural Science and Biotechnology, vol. 83, no. 4. pp. 395-400, 2008

[63] P. Martins-Lopes, J. Lima-Brito, S. Gomes, J. Meirinhos, L. Santos and H. Guedes-Pinto. "RAPD and ISSR Molecular Markers in Olea europaea L.: Genetic Variability and Cultivar Identification," Genetic Resource and Crop Evolution, vol. 54, pp. 117-128, 2007.

[64] P. Martins-Lopes, S. Gomes, J. Lima-Brito, J. Lopes and H. GuedesPinto. "Assessment of Clonal Genetic Variability in Olea europaea L. 'Cobrançosa' by Molecular Markers," Scientia Horticulturae, vol. 123, pp. 82-89, 2009.

[65] E. Kaya. "ISSR Analysis for Determination of Genetic Diversity and Relationship in Some Turkish Olive (Olea europaea L) Cultivars," Notulae Botanicae Horti Agrobotanici Cluj-Napoca, vol. 43, no. 1. pp. 96-99, 2015.

[66] J. Hess, J.W. Kadereit and P. Vargas. "The Colonization History of Olea europaea L. in Macaronesia Based on Internal Transcribed Spacer 1 (ITS-1) Sequences, Randomly Amplified Polymorphis DNAs (RAPD), and Intersimple Sequence Repeats (ISSR)," Molecular Ecology, vol. 9, pp. 857-868, 2000.

[67] A. Pasqualone, F. Caponio and A. Blanco. "Inter-Simple Sequence Repeat DNA Markers for Identification of Drupes from Different Olea europaea L. Cultivars," European Food Research Technology, vol. 213, pp. 240-243, 2001

[68] S. Pafundo, C. Agrimonti, E. Maestri, N. Marmiroli. "Applicability of SCAR Markers to Food Genomics: Olive Oil Traceability," Journal of Agricultural and Food Chemistry, vol. 5, pp. 6052-6059, 2007.

[69] M. Marieschi, A. Torelli, A. Bianch and R. Bruni. "Development of a SCAR Marker for the Identification of Olea europaea L.: A Newly Detected Adulterant in Commercial Mediterranean Oregano," Food Chemistry, vol. 126, no. 2. pp. 705-709, 2011.

[70] P. Hernández, A. Martín and G. Dorado. "Development of SCARs by Direct Sequencing of RAPD Products: Practical Tool for the Introgression and Marker-Assisted Selection of Wheat," Molecular Breeding, vol. 5, pp. 245-253, 1999.

[71] J.R. Vidal, P. Delavault, M. Coarer and A. Defontaine. "Design of Grapevine (Vitis vinifera L.) Cultivar-Specific SCAR Primers for PCR 
Fingerprinting," Theoretical and Applied Genetics, vol. 101, pp. 1194 $1201,2000$.

[72] Y. Zhang and J.R. Stommel. "Development of SCAR and CAPS Markers Linked to the Beta Gene in Tomato," Crop Science, vol. 41, pp. 1602-1608, 2001.

[73] G.P. Lee, C.H. Lee and C.S. Kim. "Molecular Markers Derived from RAPD, SCAR, and the Conserved 18S rDNA Sequences for Classification and Identification in Pyrus pyrifolia and P. Communis," Theoretical and Applied Genetics, vol. 108, pp. 1487-1491, 2004.

[74] R. Bautista, R. Crespillo and F.M. Canovas. "Identification of OliveTree Cultivars with SCAR Markers," Euphytica, vol. 129, pp. 33-41, 2003.

[75] M. Busconi, L. Sebastiani and C. Fogher. "Development of SCAR Markers for Germplasm Characterisation in Olive Tree (Olea europaea L.)," Molecular Breeding, vol. 17, no. 1. pp. 59-68, 2006.

[76] P. Hernández, R. de la Rosa, L. Rallo, and G. Dorado. "Development of SCAR Markers in Olive (Olea europaea) by Direct Sequencing of RAPD Products: Applications in Olive Germplasm Evaluation and Mapping," Theoretical and Applied Genetics, vol. 103, pp. 788-791, 2001.

[77] M. Agarwal, N. Shrivastava and H. Padh. "Advances in Molecular Marker Techniques and Their Applications in Plant Sciences," Plant Cell Reports, vol. 27, pp. 617-631, 2008.

[78] S. Reale, S. Doveri, A. Diaz, A. Angiolillo, L. Lucentini, F. Pilla, A. Martín, P. Donini and D. Lee. "SNP-Based Markers for Discriminating Olive (Olea europaea L.) Cultivars," Genome, vol. 49, no. 9. pp. 1193$1205,2006$.

[79] A. Katsiotis, T. Schmidt and J.S. Heslop-Harrison. "Chromosomal and Genomic Organization of Ty1-Copia-Like Retrotransposon Sequences in the Genus Avena," Genome, vol. 39, pp. 410-417, 1996.

[80] A. Suoniemi, K. Anamthawat-Jonsson, T. Arna and A.H. Schulman. "Retrotransposon BARE-1 is a Major, Dispersed Component of the Barley (Hordeum vulgare L.) genome," Plant Molecular Biology, vol. 30, pp. 1321-1329, 1996.

[81] A.J. Flavell, E. Dunba, R. Anderson, S.R. Pearce, R. Hartley and A. Kumar. "Ty1-Copia Group Retrotransposons are Ubiquitous and Heterogeneous in Higher Plants," Nucleic Acids Research, vol. 20, pp. 3639-3644, 1992.

[82] D.F. Voytas, M.P. Cummings, A.K. Konieczny, F.M. Ausubel and S.R. Rodermel. "Copia-Like Retrotransposons are Ubiquitous Among Plants," Proceedings of the National Academy of Sciences, vol. 89, pp. 7124-7128, 1992.

[83] S.R. Pearce, U. Pich, G. Harrison, A.J. Flavell, J.S. Heslop-Harrison, I. Schubert and A. Kumar. "The Ty1-Copia Group Retrotransposons of Allium cepa are Distributed Troughout the Chromosomes but are Enriched in the Terminal Heterochromatin," Chromosome Research, vol. 4, pp. 357-364, 1996.

[84] S.R. Pearce, G. Harrison, J.S. Heslop-Harrison, A.J. Flavell and A. Kumar. "Characterisation and Genomic Organisation of Ty1-Copia Group Retrotransposons in Rye (Secale cereale)," Genome, vol. 40, pp. $1-9,1997$.

[85] S.E. Adams, J. Mellor, K. Gull, R.B. Sim, M.F. Tuite, S.M. Kingsman and A.J. Kingsman. "The Functions and Relationships of Ty-VLP Proteins in Yeast reflect Those of Mammalian Retroviral Proteins," Cell, vol. 49, pp. 111-119, 1987.

[86] M. Shimamura, H. Yasue, K. Ohshima, H. Abe, H. Kato, T. Kishiro, M. Goto, I. Munechika and N. Okada. "Molecular Evidence from Retroposons that Whales form a Clade within Even-Toed Ungulates," Nature, vol. 388, pp. 666-670, 1997.

[87] B. Koksal, E. Kaya, K. Efe, B. Uzan and Y. Ozden-Ciftci. "Molecular Characterization of Some Turkish Olive (Olea europaea L.) Cultivars Based on IRAP Markers," 2014 World Forum on Biology, Joint Meeting of the Society for In Vitro Biology and the Society for Cryobiology, Savannah, Georgia, USA, May 31-June 4, 2014.

[88] E. Kaya and E. Yılmaz Gökdoğan. "Using Two Retrotransposon Based Marker Systems (IRAP and REMAP) for Molecular Characterization of Olive (Olea europaea L.) Cultivars," Notulae Botanicae Horti Agrobotanici Cluj-Napoca, vol. 44, no. 1. pp. 167-174, 2016.

[89] M.T. Ozkaya, E. Cakir, Z. Gokbayrak, H. Ercan and N. Taskin. "Morphological and Molecular Characterization of Derik Halhali Olive (Olea europaea L.) Accessions Grown in Derik-Mardin Province of Turkey," Scientia Horticulturae, vol. 108, pp. 205-209, 2006.

[90] N. Grati-Kamoun, F. Lamy Mahmoud, A. Rebal, A. Gargouri, O. Panaud and A. Saar. "Genetic Diversity of Tunisian Olive Tree (Olea europaea L.) Cultivars Assessed by AFLP Markers," Genetic Resources and Crop Evolution, vol. 53, pp. 265-275, 2006.

[91] A. Belaj, C. Munoz-Diez, L. Baldoni, A. Porceddu, D. Barranco and Z. Satovic. "Genetic Diversity and Population Structure of Wild Olives from the North-Western Mediterranean Assessed by SSR Markers," Annals of Botany, vol. 100, pp. 449-458, 2007.
[92] S. Stambuk, D. Sutlović, P. Bakarić, S. Petričević and Š. Anđelinović. "Forensic Botany: Potential Usefulness of Microsatellite-Based Genotyping of Croatian Olive (Olea europaea L.) in Forensic Casework," Croatian Medical Journal, vol. 48, pp. 556-562, 2007.

[93] L. Natali, T. Giordani, M. Buti and A. Cavallini. "Isolation of Ty1Copiaputative LTR Sequences and Their Use as a Tool to Analyse Genetic Diversity in Olea europaea," Molecular Breeding, vol. 19, pp. 255-265, 2007.

[94] C. Breton, C. Pinatel, F. Medail, F. Bonhomme and A. Berville. "Comparison Between Classical and Bayesian methods to Investigate the History of Olive Cultivars Using SSR-Polymorphisms," Plant Science, vol. 175, pp. 524-532, 2008.

[95] S. Doveri, F.S. Gil, A. Diaz, S. Reale, M. Busconi, A.C. Machado, A. Martın, C. Fogher, P. Donini and D. Lee. "Standardization of a Set of Microsatellite Markers for Use in Cultivar Identification Studies in Olive (Olea europaea L.)," Scientia Horticulturae, vol. 116, pp. 367373,2008

[96] D. Poljuha, B. Sladonja, E. Setic, A. Milotic, D. Bandelj, J. Jakse and B. Javornik. "DNA Fingerprinting of Olive Varieties in Istria (Croatia) by Microsatellite Markers," Scientia Horticulturae, vol. 115, pp. 223230,2008

[97] H. Hannachi, C. Breton, M. Msallem, S. Ben El Hadj, M. El Gazzah and A. Berville. "Differences Between Native and Introduced Olive Cultivars as Revealed by Morphology of Drupes, Oil Composition and SSR Polymorphisms: A Case Study in Tunisia," Scientia Horticulturae, vol. 116, pp. 280-290, 2008.

[98] B. Zitoun, V. Bronzini de Caraffa, J. Giannettini, C. Breton, A. Trigui, J. Maury, C. Gambotti, B. Marzouk and L. Berti. "Genetic Diversity in Tunisian Olive Accessions and Their Relatedness with Other Mediterranean Olive Genotypes," Scientia Horticulturae, vol. 115, pp. 416-419, 2008.

[99] T. Bracci, L. Sebastiani, M. Busconi, C. Fogher, A. Belaj and I.Trujillo. "SSR Markers Reveal the Uniqueness of Olive Cultivars from the Italian Region of Liguria," Scientia Horticulturae, vol.122, pp. 209$215,2009$.

[100]V. Alba, C. Montemurro, W. Sabetta, A. Pasqualone and A. Blanco. "SSR-based Identification Key of Cultivars of Olea europaea L. Diffused in Southern-Italy," Scientia Horticulturae, vol. 123, pp. 1116, 2009.

[101] S. Gomes, P. Martins-Lopes, J. Lopes and H. Guedes-Pinto. "Assessing Genetic Diversity in Olea europaea L. Using ISSR and SSR Markers," Molecular Biology Reports, vol. 27, pp. 365-373, 2009.

[102]I. Muzzalupo, F. Stefanizzi and E. Perri. "Evaluation of Olives Cultivated in Southern Italy by Simple Sequence Repeat Markers," Hortscience, vol. 44, no. 3. pp. 582-588, 2009.

[103]M. Sesli and E.D. Yeğenoğlu. "RAPD Assay of Wild-Type Olives in Turkey," Genetics and Molecular Research, vol. 9, no. 2. pp. 966-972, 2010.

[104]A. Belaj, C. Munoz-Diez, L. Baldoni, Z. Satovic and D. Barranco. Genetic "Diversity and Relationships of Wild and Cultivated Olives at Regional Level in Spain," Scientia Horticulturae, vol. 124, pp. 323330,2010

[105]C. Durgac, Y. Kiyga and M. Ulas. "Comparative Molecular Analysis of Old Olive (Olea europaea L.) Genotypes from Eastern Mediterranean Region of Turkey," African Journal of Biotechnology, vol. 9, no. 4. pp. 428-433, 2010.

[106]M. Sesli and E.D. Yeğenoğlu. "Comparison of Manzanilla and Wild Type Olives by RAPD-PCR Analysis," African Journal of Biotechnology, vol. 9, no. 7. pp. 986-990, 2010.

[107]E. Albertini, R. Torricelli, E. Bitocchi, L. Raggi, G. Marconi, L. Pollastri, G. Di Minco, A. Battistini, R. Papa and F. Veronesi. "Structure of Genetic Diversity in Olea europaea L. Cultivars from Central Italy," Molecular Breeding, vol. 27, pp. 533-547, 2011.

[108]G. Corrado, A. Imperato, M. La Mura, E. Perri and R. Rao. "Genetic Diversity Among Olive Varieties of Southern Italy and the Traceability of Olive Oil Using SSR Markers," Journal of Horticultural Science \& Biotechnology, vol. 86, no. 5. pp. 461-466, 2011.

[109]S. Ercisli, A. Ipek and E. Barut. "SSR Marker-Based DNA Fingerprinting and Cultivar Identification of Olives (Olea europaea)," Biochemical Genetics, vol. 49, pp. 555-561, 2011.

[110]A.A. Awan, M. Zubair, A. Iqbal, S.J. Abbas and N. Ali. "Molecular Analysis of Genetic Diversity in Olive Cultivars," African Journal of Agricultural Research, vol. 6, no. 21. pp. 4937-4940, 2011.

[111]A.H. Beiki, S. Saboor and M. Ebrahimi. "A New Avenue for Classification and Prediction of Olive Cultivars Using Supervised and Unsupervised Algorithms," Plos One, vol. 7, no.9. pp. 1-9, 2012.

[112] S.G. Atienza, R. De la Rosa, M.C. Domínguez-García, A. Martín, A. Kilian and A. Belaj. "Use of DArT Markers as a Means of Better Management of the Diversity of Olive Cultivars," Food Research International, vol. 54, pp. 2045-2043, 2013. 
[113]E. Figueiredo, J. Canhoto and M.M. Ribeiro. "Fingerprinting and Genetic Diversity of Olea europaea L. ssp. europaea Accessions from the Cultivar Galega Using RAPD Markers," Scientia Horticulturae, vol. 156, pp. 24-28, 2013.

[114]A. Cicatelli, T. Fortunati, I. De Feis and S. Castiglione. "Oil Composition and Genetic Biodiversity of Ancient and New Olive (Olea europea L.) Varieties and Accessions of Southern Italy,” Plant Science, vol. 210, pp. 82-92, 2013.

[115]A. Belaj, M.A. Ojeda, C. Muñoz, E. Rodríguez, A. Díaz, P. Rallo, R. De la Rosa, D. Barranco, L. Rallon and I. Trujillo. "The Use of Molecular Markers to Characterize Olive (Olea europaea L.) Germplasm and its Wild Relatives," OliveBioteq, pp. 391-396, 2006.

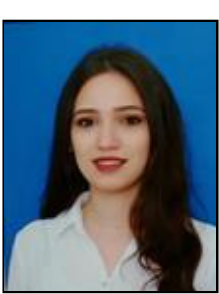

\section{Mrs. Selin Galatali}

Research Assistant in Molecular Biology (Mugla Sitki Kocman University, Tukey). Her research interests are in the areas of plant biotechnology and plant molecular biology. She investigates cold stress genes of in vitro grown plant species at transcriptional levels.

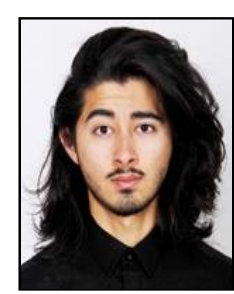

Mr. Naeem Abdul Ghafoor

He is a student of the Department of Molecular Biology and Genetics, Mugla Sitki Kocman University, Turkey). His research interests are in molecular phylogeny and bioinformatics.

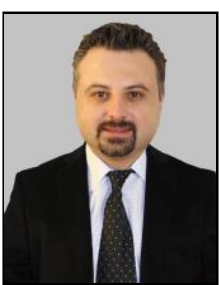

\section{Assoc. Prof. Dr. Ergun Kaya}

He earned his Ph.D. in Molecular Biology and Genetics at Gebze Technical University, Turkey, and served as a post-doctoral fellow in Plant Biotechnology at Colorado State University, National Center for Genetic Resources Preservation (USA). His primary research interests are plant biotechnology, plant molecular biology. 